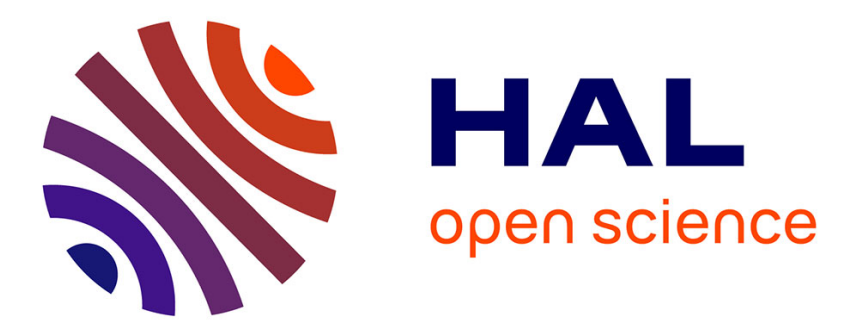

\title{
Treatment of septage in sludge drying reed beds: a case study on pilot-scale beds
}

Stephane Troesch, Alain Lienard, Pascal Molle, Gerard Merlin, Dirk Esser

\section{To cite this version:}

Stephane Troesch, Alain Lienard, Pascal Molle, Gerard Merlin, Dirk Esser. Treatment of septage in sludge drying reed beds: a case study on pilot-scale beds. Water Science and Technology, 2009, 60 (3), pp.643-653. hal-00453160

\section{HAL Id: hal-00453160 https://hal.science/hal-00453160}

Submitted on 4 Feb 2010

HAL is a multi-disciplinary open access archive for the deposit and dissemination of scientific research documents, whether they are published or not. The documents may come from teaching and research institutions in France or abroad, or from public or private research centers.
L'archive ouverte pluridisciplinaire HAL, est destinée au dépôt et à la diffusion de documents scientifiques de niveau recherche, publiés ou non, émanant des établissements d'enseignement et de recherche français ou étrangers, des laboratoires publics ou privés. 


\title{
Treatment of septage in sludge drying reed beds: a case study on pilot-scale beds
}

\author{
S. Troesch***, A. Liénard*, P. Molle*, G. Merlin**, D. Esser*** \\ * Cemagref, UR QELY, Water Quality and Pollution Control Research Unit, 3bis, quai Chauveau, CP 220, \\ F69336-LYON Cedex 09,France E-mail: alain.lienard@cemagref.fr, pascal.molle@cemagref.fr \\ ** Laboratoire Optimisation de la Conception et Ingénierie de l'Environnement, Polytech'Savoie- Université \\ de Savoie, 73376 Le Bourget du Lac, France E-mail: gerard.merlin@univ-savoie.fr \\ *** Société d'Ingénierie Nature \& Technique, 5 rue Boyd 73100 Aix les Bains, France \\ E-mail: stephane.troesch@cemagref.fr, dirk.esser@sint.fr
}

\begin{abstract}
French legislation requires, the control of private on-site sanitation systems by local authorities. This will result in a large increase of the quantity of sludge from septic tanks to be treated. Nevertheless, large wastewater treatment plants are not systematically able to treat this sludge because they may have reached their nominal load or they are not so numerous in rural zone to avoid too long transportation. The study concerns both, the feasibility of sludge reed beds devoted to the treatment of septage and the assessment of a simultaneous treatment with aerated sludge. The experiments have been carried out on eight pilot-scale drying reed beds $\left(2 \mathrm{~m}^{2}\right)$ planted with Phragmites australis. Two filtration layers of either vegetal compost or sand were tested. The study is focused on the commissioning period (first vegetative year) with a loading rate of 30 $\mathrm{kgSS} . \mathrm{m}^{-2} \cdot \mathrm{yr}^{-1}$. According to these operational conditions, dewatering efficiencies reached approx. 30\% DM during summer but less than 20\%DM in winter for each filtration layer and sludge. High removal efficiencies, with an average of $96 \%, 92 \%$ and $89 \%$ for SS, COD and TKN respectively, were achieved with septage whereas they were lower for the mixture of aerated sludge and septage.

The dewaterability of septage and its filtration behaviour were assessed by several parameters (Capillary Suction Time, bound water) which may be some interesting tools for an optimised loading strategy.

Keywords: septage, sludge drying, reed beds, performances, commissioning period, pilot plants
\end{abstract}

\section{INTRODUCTION}

In France, on-site sanitation is recognised to be an alternative technique to centralised wastewater treatment. Taking in account the obligation of regulatory control of on-site wastewater treatment of dwelling houses, communities are now facing larger volumes of septage. Its main destination is direct agricultural reuse or co-treatment with wastewater in treatment plants larger than 10000 P.E. While the first solution is not well accepted (sanitary risks, high septicity and ammonia concentration leading to odour inconveniences), the second is not always achievable. In fact large wastewater treatment plants are either not so numerous in rural areas or not systematically able to treat an additional organic load. Moreover, it is environmentally and economically undesirable to have too long transportation.

In this context, Cemagref undertook studies to better characterize this septage and optimize its specific treatment (without any chemical pre treatment) on sludge drying reed beds.

But, most of the actual experience gained in sludge drying reed bed concerns essentially activated sludge where a general design of $50 \mathrm{kgDM} . \mathrm{m}^{-2} \cdot \mathrm{yr}^{-1}$ and at least 6-8 beds are recommended (Liénard et al., 1995; Mellstrom and Jager, 1994; Nielsen, 2003). It is admitted that reduction of the amount of sludge occurs (Burgoon et al., 1997; Hofmann, 1990; Liénard et al., 1995; Nielsen, 2003; Pempkowiak and Obarska-Pempkowiak, 2002) both with dewatering (drainage and evapotranspiration) and aerobic mineralisation. The main idea of this study is to transfer this knowledge to septage treatment.

A literature review on the use of sludge drying reed beds for septage or anaerobic sludge treatment (Koottatep et al., 2005; Liénard and Payrastre, 1996; Nielsen, 2003) shows that bed design and area loading rate varies a lot according to the sludge quality and climate: $40 \mathrm{kgSS}_{\mathrm{m}} \mathrm{m}^{-2} \cdot \mathrm{yr}^{-1}$ (Liénard, 
2004), 50kgDM.m ${ }^{-2} \cdot \mathrm{yr}^{-1}$ and minimum 10-12 basins (Nielsen, 2003) and 250kgDM.m ${ }^{-2} \cdot \mathrm{yr}^{-1}$ (Koottatep et al., 2005).

But an ignorance of the concerned mechanisms tend to empiricism and uncertainties in bed design (number of beds, composition of the filtration layer) and operation strategy (organic load, feeding/rest periods...) which lead to anaerobic conditions and poor vegetation growth (essentially during the commissioning phase), insufficient drainage and clogging phenomenon (Nielsen, 2003; 2005).

\section{METHODS AND MATERIALS}

\section{Dewaterability}

This parameter can be defined either by estimation of the bound water (centrifugation, thermo gravimetry or dilatometry methods) or with the filterability (specific resistance to filtration, capillary suction time). Nevertheless, as many sludge characteristics are believed to affect the dewaterability like particle size distribution, organic content, cationic salts, extra cellular substances, they also need to be analysed (Vaxelaire and Cezac, 2004).

The capillary Suction Time (CST) seems to prevail in establishing the determination of sludge dewaterability (Huisman and Van Kesteren, 1998). It is a good and convenient indicator to approach the sludge concentration and average specific resistance (Chen et al., 1996) in spite of its limits in predicting physical characteristics such as the bound water.

Nielsen uses this apparatus as a dimensioning tool to precise the loads and the number of beds that have to be used (Nielsen, 2003) and wonder if sludge can be applied without dilution when CSTs are greater than $1000 \mathrm{sec}$.

To precise the interest of CST, these measures were done by a Triton Electronics Ltd.(C) $304 \mathrm{M}$ apparatus (10mm cylinder well).

In parallel, bound water measurement have been done thanks to a thermo balance (Kern MRS1203 ) used at $105^{\circ} \mathrm{C}$ and 10-20\% of humidity. The water distribution can be derived from the curve of the drying rate in relation to the moisture content of the sample (Kopp and Dichtl, 2000; Vaxelaire and Cezac, 2004).

\section{Sludge preparation}

As septage is the result of anaerobic processes in the septic tank, it is composed of a lot of tiny and non-flocculated particles in suspension in a liquid fraction where many salts are dissolved (ammoniacal nitrogen, volatile fatty acids, orthophosphates ...) resulting in high electric conductivity values $\left(>2500 \mu{\mathrm{S} . \mathrm{cm}^{-1}}^{-1}\right.$. The main consequences are a difficult solid/liquid separation and a decrease of the dewaterability. Therefore different sludge preparations have been tested during the experiment like:

- Treating directly septage on the reed beds: the interest results in the simplicity and the economical aspect of such a process.

- Mixing septage with aerated sludge: the aim is to take advantage of the flocculation of the aerated sludge itself or its supernatant (treated WW) to increase the dewaterability of the mixture through a flocculation improvement (Sanin and Vesilind, 1994).

The choice of the type of the diluting agent (aerated sludge, treated WW) and the ratio of dilution has been made thanks to Jar-test and CST measurement (Fig1 and 2). 




Figure 1: Sludge dewaterability (CST) at different suspended solids concentration obtained with septage supernatant, WWTP outlet, or with aerated sludge dilutions.

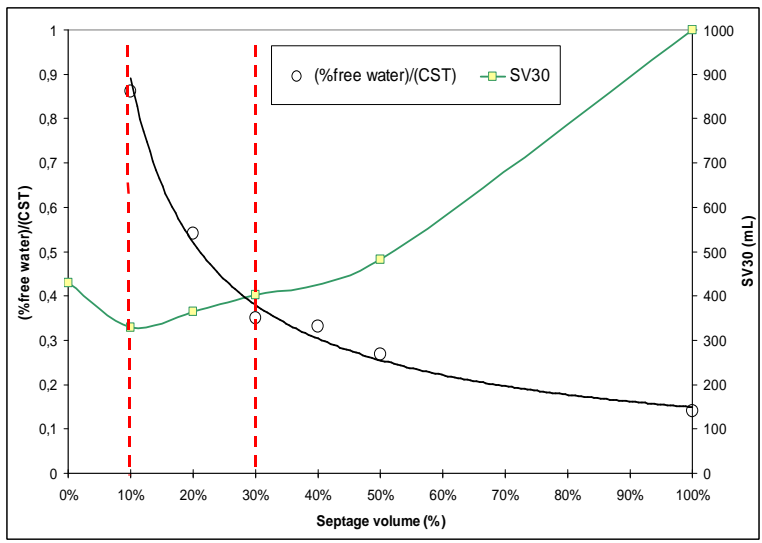

Figure 2: Dewaterability and settled volume after $30 \mathrm{~min}$ in a 1liter test tube (SV30) at different septage/aerated sludge volume ratio $([\mathrm{SS}]$ septage $=$ $26,3 \mathrm{~g} / \mathrm{l},[\mathrm{SS}]$ aerated sludge $=1,6 \mathrm{~g} / \mathrm{l})$

Diluting septage with aerated sludge appears to be the best choice to reduce CST (Fig 1). The ratio used in this experiment has been fixed to $20 \%$ of septage because it represents a good compromise to improve the dewaterability (high freewater/low CST) and the sludge volume index (Fig 2).

Flocculation of septage with a chemical coagulation/flocculation product has not been chosen because it was not really effective (results not shown) and not economically attractive.

\section{The pilot-scale beds}

The experiments were performed on 8 experimental concrete beds of $2 \mathrm{~m}^{2}$ each built close to an extended aeration activated sludge plant (Andancette, $13000 \mathrm{PE}$, France). 9. $\mathrm{m}^{-2}$ clumps of one year old Phragmites australis plantlets were planted in May 2006. The pilots only differ in the top layer filtration to test the importance of capillary connection on water drainage. We used $5 \mathrm{~cm}$ of sand $(\mathrm{d} 10=0.35, \mathrm{UC}=3.2)$ or $10 \mathrm{~cm}$ of vegetal compost from a composting platform according to the French standard NF U 44-051. Six pilots are fed exclusively with septage while two other one are fed with the activated-septage mixture. Pilot design and loading characteristics are presented in Fig 3 and 4.

During the first half-year after planting, the pilots were fed with treated wastewater for good acclimatization of the reeds. After what a 1.5 year commissioning period started in January 2007 with an area-loading rate of $30 \mathrm{kgSS} \cdot \mathrm{m}^{-2} \cdot \mathrm{yr}^{-1}$ for all the pilots in order to ensure a good reed establishment (reed density of $200 \mathrm{stem} \cdot \mathrm{m}^{-2}$ ).

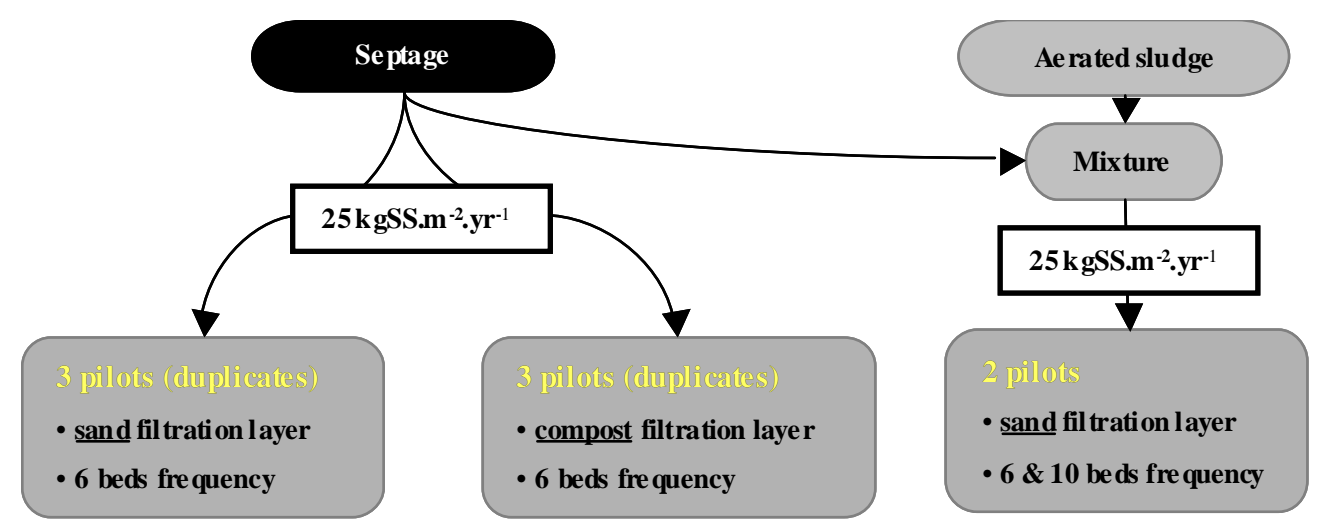

Figure 3: Top filtration layer and feeding strategy of the pilots during the commissioning period 
Two feeding frequencies were tested for the pilots fed with the septage/activated sludge mixture which simulate a configuration of 6 and 10 drying reed beds in parallel. Feeding and rest ratio are summarized in Table 2.

Inlet flow was determined by measuring the time of functioning of the pump whereas the outlet flow were measured by the level of drained water by a pressure probe (STS). Infiltration rates (IR) were quantified by measuring the level of temporary excess surface water level with ultrasounds probes.

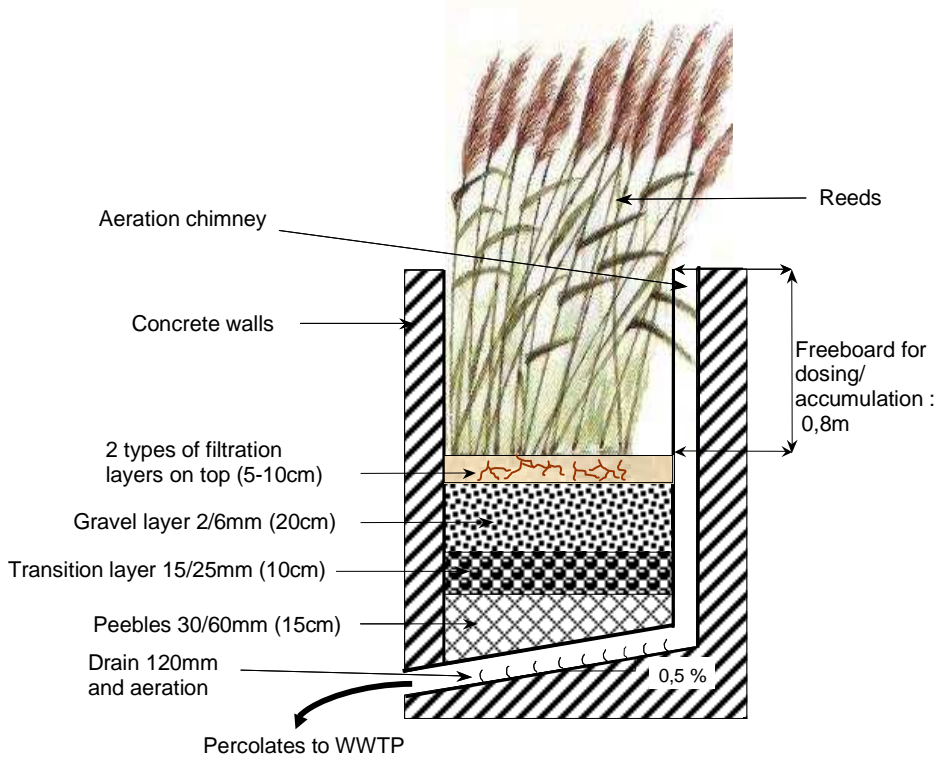

Figure 4: Cross-section of a pilot plant

\section{Chemical measurements}

The percolation flow quality was assessed only the last day of a feeding cycle (except for SS where a measure was done every loading day) and was sampled $24 \mathrm{~h}$ after the feeding. Each pilot was evaluated for, $\mathrm{COD}, \mathrm{SS}, \mathrm{KN}, \mathrm{NH}_{4}-\mathrm{N}, \mathrm{NO}_{3}-\mathrm{N}$, TP and $\mathrm{PO}_{4}-\mathrm{P}$ according to French standard methods (AFNOR, 2005a). The removal rates are calculated in mass flux $\left(\left[\mathrm{C}_{\mathrm{in}} * \mathrm{~V}_{\mathrm{in}}-\mathrm{C}_{\text {out }} * \mathrm{~V}_{\text {out }}\right] /\left[\mathrm{C}_{\text {in }} * \mathrm{~V}_{\text {in }}\right]\right)$. With $\mathrm{C}_{\mathrm{in}}$ :.

\section{Residual sludge quality}

The dry matter (DM) content of the residual sludge was firstly assessed in November 2007 when the thickness of the residual sludge layer achieved approximately $6 \mathrm{~cm}$. Two samples were taken in each pilot and were dried at $105^{\circ} \mathrm{C}$ during $24 \mathrm{~h}$.

Aerobic conditions into the sludge were assessed with a redox measurement set for soil (Eijkelkamp, 18.28.SC). The measured values are converted to the redox potential by comparison to the Standard hydrogen electrode (SHE)

Once a week, $\mathrm{O}_{2}, \mathrm{CO}_{2}$ and $\mathrm{CH}_{4}$ measurements were made by a Dräger $\mathrm{X}$ am 7000 sensor just under the filtration layer to follow their respective concentration percentages in the gas phase.

Sludge humification and its grade of stabilization were assessed by several indicators like the organic matter (loss of ignition), the biologic stability indicator (BSI) and biochemical organic matter characterization (BMC). These two last indicators give the organic matter percentage which could resist to mineralization when spread on land. (AFNOR, 2005b).

Therefore, the residual sludge have been sampled in the bottom layer $(5-10 \mathrm{~cm}$ depth $)$ of the residual sludge deposit at 6 different points at the end of the commissioning period in May 2008 (sludge 12 to 18 months old) after 25 days of rest. Pathogenic micro-organisms (Enterococci, Clostridium perfringens and E.Coli) were assessed on the same samples according to French standard methods (AFNOR, 1994; 1998; 2002).

\section{RESULTS AND DISCUSSION}

\section{Influent sludge quality}

Septage used to feed the pilots was discharged in a stirred storage tank of the plant and comes from either old fashioned septic tanks (black water only) or new "all-waters tanks" (grey and black waters). Only a $10 \mathrm{~mm}$ mesh screening is applied to septage before being stored in the tank. Table 1 summarises its quality. 
Table 1: Physico-chemical characteristics of the septage during de commissioning period (Jan 07 - Jan 08)

\begin{tabular}{|c|c|c|c|c|c|}
\hline & Average & Max & Min & $\begin{array}{l}\text { Standard } \\
\text { deviation }\end{array}$ & Nb. of values \\
\hline$\overline{\mathrm{CST}(\mathrm{sec})}$ & 398 & 688 & 174 & 153 & 14 \\
\hline Bound water (\%) & $31 \%$ & $51 \%$ & $13 \%$ & $19 \%$ & 3 \\
\hline $\mathrm{pH}$ & 7,3 & 7,7 & 6,9 & 0,3 & 11 \\
\hline Cond $(\mu$ S.cm-1) & 3400 & 5920 & 2230 & 923 & 12 \\
\hline $\mathrm{DM}(\mathrm{mg} / \mathrm{l})$ & 33672 & 50800 & 11639 & 10499 & 16 \\
\hline $\mathrm{SS}(\mathrm{mg} / \mathrm{l})$ & 26955 & 45020 & 6704 & 9926 & 18 \\
\hline VS (\%DM) & $68 \%$ & $79 \%$ & $51 \%$ & $6 \%$ & 18 \\
\hline $\mathrm{COD}(\mathrm{mg} / \mathrm{l})$ & 46255 & 60763 & 20020 & 11070 & 12 \\
\hline $\mathrm{N}-\mathrm{KNt}(\mathrm{mg} / \mathrm{l})$ & 1546 & 2462 & 818 & 437 & 12 \\
\hline $\mathrm{N}-\mathrm{NH}_{4}^{+}(\mathrm{mg} / \mathrm{l})$ & 308 & 441 & 175 & 80 & 12 \\
\hline 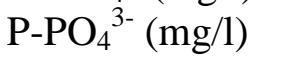 & 48 & 60 & 36 & 17 & 2 \\
\hline $\mathrm{TP}(\mathrm{mg} / \mathrm{l})$ & 606 & 810 & 469 & 180 & 3 \\
\hline
\end{tabular}

The septage characteristics exhibit high variations for most of the parameters. This is due to different factors: varying ratio of sludge and liquid pumped by the vacuum truck, ratio tank volume/number of inhabitants and the emptying frequency.

The high CST values and bound water percentage indicate a low dewaterability compared to activated sludge (typically at a level of approx. $7 \mathrm{sec}$ ). This poor dewaterability is partly due to the particle size distribution of septage and its high fines content (Figure 5). Indeed, (Karr and Keinath, 1978) have mentioned that the higher the proportion of supracolloidal solids ( 1 to $100 \mu \mathrm{m}$ ) is, worst is the dewaterability. This is due to clogging of the sludge cake and filter medium by the particles of this size range.

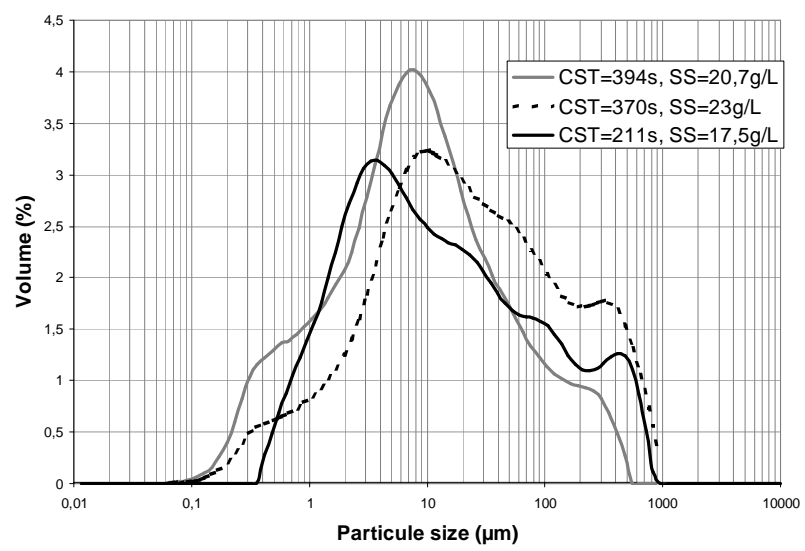

Figure 5: Three septage particle size distribution in volume obtained by means of a laser granulometer (Malvern Mastersizer)

\section{Sludge dose and accumulation}

The mean accumulation rate of sludge is about $11,5 \mathrm{~cm} \cdot \mathrm{yr}^{-1}$ for pilots composed with a sand filtration layer while septage treatment with a compost filtration layer have a lower accumulation rate partly due to i) a lower filtration efficiency during the first loadings, ii) a higher density of reeds which lead in a better sludge porosity, iii) probably a better surface cracked sludge phenomena. Despite the low septage dewaterability (fine particles and high CST) no bed clogging 
was observed during the commissioning period. The low hydraulic and organic loading rates with adequate rest period have led to good reed establishment and dewatering efficiencies.

Table 2: Area loading rate and accumulation rate during the commissioning period (1,5 year)

\begin{tabular}{|c|c|c|c|c|c|c|c|c|c|c|c|}
\hline \multirow[t]{2}{*}{ Sludge } & \multirow[t]{2}{*}{$\begin{array}{c}\text { Filtration } \\
\text { layer }\end{array}$} & \multirow[t]{2}{*}{$\begin{array}{l}\text { Nb. of } \\
\text { beds }\end{array}$} & \multirow{2}{*}{$\begin{array}{l}\text { Feeding/ } \\
\text { rest } \\
\text { period } \\
\text { (d/d) }\end{array}$} & \multirow{2}{*}{$\begin{array}{c}\text { Hydraulic } \\
\text { load * } \\
\left(\text { cm.d }^{-1}\right)\end{array}$} & \multirow{2}{*}{$\begin{array}{c}\text { loading } \\
\text { rate } \\
\left(\text { kgSS.m }^{-}\right. \\
\left.{ }^{2} . \mathrm{yr}^{-1}\right)\end{array}$} & \multirow[t]{2}{*}{$\begin{array}{l}\text { Acc. rate } \\
\left(\mathbf{c m} \cdot y^{-1}\right)\end{array}$} & \multirow[t]{2}{*}{$\begin{array}{c}\text { Reed } \\
\text { density* }\end{array}$} & \multirow[t]{2}{*}{$\begin{array}{l}\text { DM** } \\
(\%)\end{array}$} & \multirow[t]{2}{*}{$\begin{array}{l}\text { VS** } \\
(\% \mathrm{DM})\end{array}$} & \multicolumn{2}{|c|}{$\begin{array}{l}\text { Pathogen } \\
\text { removal } * * \\
\text { (log unit) }\end{array}$} \\
\hline & & & & & & & & & & E-Coli & Entero \\
\hline \multirow{2}{*}{ Septage } & Compost & 6 & $3.5 / 17.5$ & $2.8 \pm 1.3$ & 32 & $8.4+/-0.6$ & $271 \pm 33$ & 27.9 & 58.8 & 2 & 2 \\
\hline & Sand & 6 & $3.5 / 17.5$ & $2.8 \pm 1.3$ & 32 & $11.3+/-0.6$ & $266 \pm 123$ & 26.9 & 56.0 & 3 & 2 \\
\hline \multirow{2}{*}{ Mixture } & Sand & 6 & $3.5 / 17.5$ & $10.2 \pm 5.9$ & 33 & $11.9+/-0.6$ & 338 & 24.9 & 54.4 & 4 & 2 \\
\hline & Sand & 10 & $3.5 / 31.5$ & $14.1 \pm 5.0$ & 29 & $11.6+/-0.6$ & 224 & 28.4 & 55.2 & - & - \\
\hline
\end{tabular}

*Mean Hydraulic load during each feeding days

**Sampled in the bottom layer ( $5-10 \mathrm{~cm}$ below the sludge deposit surface) at the end of the commissioning period after a 25 days of rest

\section{Plant growth}

The initial planting density of 9 pots $/ \mathrm{m}^{2}$ has led to a mean density of 160 and 200 stems. $\mathrm{m}^{-2}$ during the first season growth (June 2007) on pilots composed with a sand and compost filtration layer respectively fed with septage. Nevertheless, in July 2007 on all pilots, the reeds showed signs of wilting due to a lack of water because the amount of sludge was not sufficient to provide enough water. Therefore the pilots have been saturated with treated WW until $5 \mathrm{~cm}$ under the filtration layer during 20 days. This operation allowed the reeds to recover and become healthy again within 3 weeks. In order to limit wilting on the 10 beds frequency (fed with septage and aerated sludge mixture), we have shorten its cycle length from 35 to 20 days by decreasing the feeding period to 2 days during four months (Jul 07 - Nov 07).

Despite a faster colonization rate was observed on compost filtration layer, the reeds have reached an equal density $\left(\approx 250\right.$ stems. $\left.\mathrm{m}^{-2}\right)$ on both filtration media at the end of the spring (May 2008) with the septage loading.

Finally, at the end of the commissioning period with a specific loading rate of $30 \mathrm{kgSS} \cdot \mathrm{m}^{-2} \cdot \mathrm{yr}^{-1}$, the following observations can be pointed out:

- Sludge quality (septage or mixture) did not impact the reed growth,

- A maximum of 3 and 2 days feeding period followed by maximum 20 days of rest is recommended for a 6 and 10 beds configuration respectively to avoid wilting of the reeds,

- The vegetal compost layer ensures a better growing media and may improve capillary connection with the residual sludge than sand,

- No toxic effect on reed growth was assessed despite the septicity of septage and the low redox potential observed in the sludge layer.

Finally, after the second growing season pilots reached a similar reed density than those observed in the full-scale reed beds fed with aerated sludge at nominal load. It could also be concluded that the system is able to run at its full capacity after a commissioning period allowing a reed density of at least 250 stems. $\mathrm{m}^{-2}$.

\section{Dewatering performances / Residual sludge quality}

Dewatering. During feeding periods, drainage flow was very low (max outflow average of 0,16 L $\min ^{-1} \cdot \mathrm{m}^{-2}$ ) due to low hydraulic loading rate (Table 2)and the clogging power of septage. Therefore the drainage takes several days and a minimum rest period of 15 days seems to be necessary.

Dewatering performances are:

- similar whatever the filtration layer when feeding by septage (Table 3) 
- affected by the feeding strategies (6 - 10 beds) when pilot are fed by mixture sludge (Table 3) .

Table 3: Dry matter content of the sludge deposit according to the type of sludge, the number of bed and the season

\begin{tabular}{cccccc}
\hline Type of sludge & Number of bed & $\begin{array}{c}\text { DM summer } \\
(\%)\end{array}$ & $\begin{array}{c}\text { Temperature } \\
\left({ }^{\circ} \mathrm{C}\right)\end{array}$ & $\begin{array}{c}\text { DM winter } \\
(\%)\end{array}$ & $\begin{array}{c}\text { Temperature } \\
\left({ }^{\circ} \mathrm{C}\right)\end{array}$ \\
\hline Septage & 6 & $32 \pm 3 \%$ & & $23 \pm-1 \%$ & \\
Mixture & 6 & $24 \%$ & $17 \pm 3{ }^{\circ} \mathrm{C}$ & $19 \%$ & $7 \pm 4{ }^{\circ} \mathrm{C}$ \\
& 10 & $31 \%$ & & $25 \%$ & \\
\hline
\end{tabular}

The desiccation rates are improved in summer due to evapotranspiration. Water loss on pilots fed with septage (with a reed density of approx. 200 stems. $\mathrm{m}^{-2}$ ) was estimated (by hydraulic balance sheet) to be $3,6 \mathrm{~mm} / \mathrm{d}$ in summer and $1,8 \mathrm{~mm} / \mathrm{d}$ in winter due to evaporation and plant transpiration.

Residual sludge aeration. Redox potential (ORP) variations in residual sludge layer (Figure 6) show that aerobic conditions $(\geq 200 \mathrm{mV} / \mathrm{EHN})$ is achievable with difficulty under low air temperature $\left(\leq 16^{\circ} \mathrm{C}\right)$ after a 18 days rest period whatever is the kind of sludge. During winter (low temperature, no or weak metabolic activity ) the sludge piles up in the bed and is subject to low dewatering. Due to septage septicity and limitation of oxygen diffusion in winter, ORP is low despite good oxygen concentration in the air at the bottom of the beds $\left(18,9 \pm 1,1 \mathrm{O}_{2} \%\right)$. Once air temperature increases, the biological activity is stimulated resulting in an increase in oxygen demand (we measured a slight methane concentration of $0,14 \% \mathrm{CH} 4$ in the filtration layer) and ORP remains low. Sufficient mineralisations of the sludge accumulated in winter as well as a sufficient plant growth are needed to recover a good infiltration rate and oxygen renewal. The increase of the ORP at levels corresponding to aerobic conditions occurs 10-15 days after the increase of the temperature. After that, ORP remains high because:

- the surface of the sludge cracked (mean $\mathrm{T}^{\circ} \mathrm{C}>16^{\circ} \mathrm{C}$ ) and its higher porosity due to the reeds growth allowing both better oxygen renewal and water infiltration,

- reeds favour aerobic conditions (oxygen release) and aerobic conditions are appreciated by reeds (growth rate). The oxygen release by the reeds creates oxidized zones around the roots in the sludge (Hofmann, 1990). Sludge sampling clearly shown a good roots colonization, so that we observed a direct relation between ORP in the sludge and plant density (Figure 7)

- When aerobic conditions are well-established micro-organisms and earthworms decompose the organic matter and favour also water infiltration and oxygen diffusion. We also observed that the compost filtration layer favours the presence of earthworms.

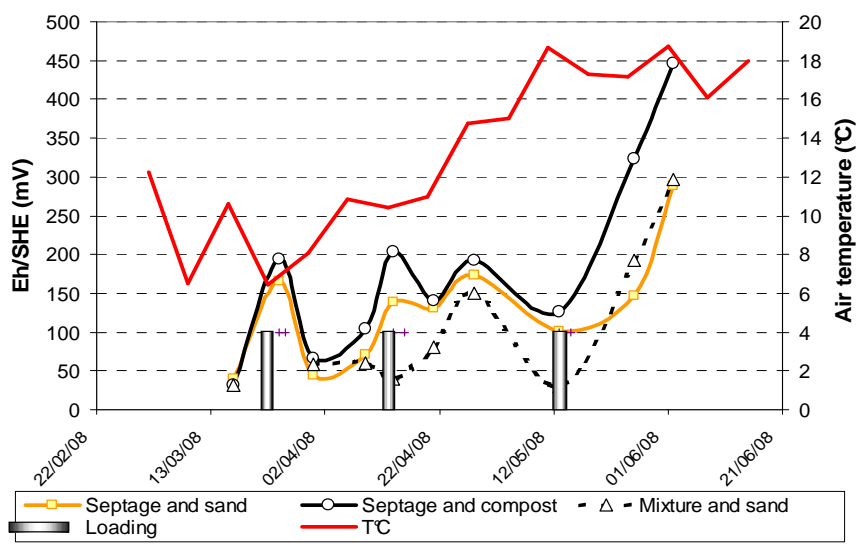

Figure 6: Redox potential variations in residual sludge in the experimental beds fed with septage or mixture

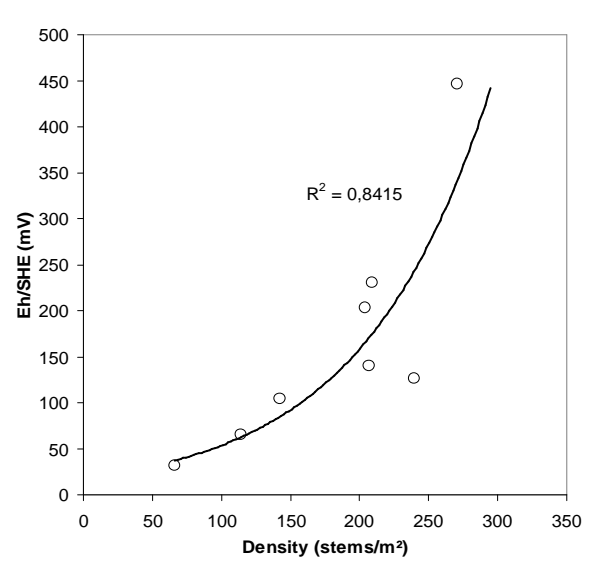

Figure 7: Correlation between reed density and redox potential of the sludge deposits for pilots fed with septage with a compost filtration layer and during the 
Humification. Together with dehydration humification of the sludge is a very important process to reduce the sludge volume and its content of organic compounds unfavourable for dewatering properties. It has been shown that a lower organic fraction leads to a higher total drainable water volume (Kopp and Dichtl, 2000).

The average content of organic matter $[\mathrm{OM}]$ measured in the pilots fed with septage is $57 \%$, whereas the OM content of septage is $68 \%$. This indicates that approximately $16 \%$ of organic matter loaded was decomposed in $\mathrm{CO}_{2}, \mathrm{H}_{2} \mathrm{O}$ and minerals.

The mineralization is better in the pilots fed with mixture at a 6 beds frequency. They showed an organic matter decrease of $19,3 \%$ d.m from $67,4 \%$ (fresh sludge) to $54,4 \%$ (bottom residual sludge). Such a difference observed between both kinds of sludge is logical because septage is stored for several years in septic tank and subject to a prior anaerobic decomposition resulting in a $\mathrm{COD} / \mathrm{BOD}_{5}$ ratio of approx 5-6.

The high BSI and BMC values (100 and 60\% respectively) for septage (on both filtration media) indicate that organic matter is intrinsically resistant to mineralization and highly humified after a 1,5 year storage in the pilots. The results for the mixture (73,2 and 46,8\% respectively) also indicate a good stability of this product close to the one of a vegetal compost and its land valorisation will give approximately $100 \mathrm{~kg}$ of humus per ton.

Pathogen removal. Besides physical and chemical influences (heat, radiation, alkalinity), biological processes reduce the density of pathogens in sewage sludge. These biological processes take place during the humification of septage sludge and lead to attenuation of pathogen bacteria. The main factors that threat bacteria are UV radiation, high or low $\mathrm{pH}$, predators like protozoa and most organisms are not resistant to dessication (Pabsch, 2004). Other reasons responsible of pathogen removal are earthworms when digesting the organic matter or various organic substances (antibiotics) secreted by some plants or micro-organisms (Pabsch, 2004).

In septage used to feed the pilots, the levels of E. Coli and Enterococci were 4,2 $\pm 3,7.10^{6} \mathrm{MPN} / \mathrm{g}$ (dry weight) and 5,9 $\pm 6,9.10^{6} \mathrm{MPN} / \mathrm{g}$ (dry weight) respectively. The mixture have a similar pathogen

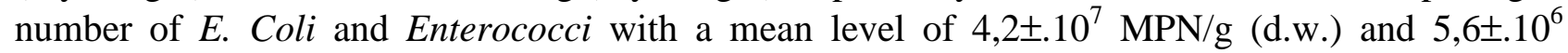
MPN/g (d.w.) respectively. Analysis made on all pilots after 25 days of rest in the 5-10cm layer of sludge below the surface reveal a pathogen reduction ranging between 2-4 log unit (d.w) (Table 3). These results are consistent with those obtained by (Nielsen, 2007). Clostridium perfringens was the most persistent among the bacteria studied: $3.10^{6}$ cells/g (wet weight) for pilot fed with the mixture and over $6.10^{6}$ cells/g (wet weight) for pilots fed with septage, whereas the limit fixed by the NF U 44-095 standard (actual criteria for compost carried out from sludge) requires only $10^{3}$ cells/g (wet weight). Nevertheless, these results are far better than those of a mechanically dewatered sludge.

\section{Percolation flow quality}

The water quality of the leachates is presented in table 4. Besides the good removal rates, even for nitrification, it can be seen that SD calculated on concentrations of most pollutants are high, particularly for the filtration layer made of vegetal compost. This phenomena is explained by:

- Deficient filtration when the sludge layer is thin and when the sludge deposits are cracked. Once the sludge layer is high, this effect is strongly diminished.

- The high heterogeneity of septage quality.

- The small size of solid particles present in the septage (see Fig 4). Particle size analysis of inlet and outlet WW allow to observe that filtration becomes effective for particle size greater than $60 \mu \mathrm{m}$ and $90 \mu \mathrm{m}$ for sand and compost respectively. This represent $79 \pm 9 \%$ $\mathrm{v} / \mathrm{v}$ and $83 \pm 7 \% \mathrm{v} / \mathrm{v}$ respectively of solids that are poorly stopped by the filter. 
Table 4: Leachate contents and removal performances for pilots fed with septage (commissioning period)

\begin{tabular}{lcccccccc}
\hline & \multicolumn{4}{c}{ Compost } & \multicolumn{4}{c}{ Sand } \\
\hline Parameters & $\begin{array}{c}\text { Mean } \\
\text { result }\end{array}$ & $\begin{array}{c}\text { Standard } \\
\text { Deviation }\end{array}$ & $\begin{array}{c}\text { Removal } \\
\text { rate }\end{array}$ & $\begin{array}{c}\text { Nbr. of } \\
\text { sample }\end{array}$ & $\begin{array}{c}\text { Mean } \\
\text { result }\end{array}$ & $\begin{array}{c}\text { Standard } \\
\text { Deviation }\end{array}$ & $\begin{array}{c}\text { Removal } \\
\text { rate }\end{array}$ & $\begin{array}{c}\text { Nbr. of } \\
\text { sample }\end{array}$ \\
\hline pH & 8,0 & 0,3 & - & 29 & 7,9 & 0,3 & - & 27 \\
Cond $(\mu \mathrm{S} . c \mathrm{~cm}-1)$ & 3416 & 1043 & - & 31 & 3144 & 1100 & - & 30 \\
$\mathrm{SS}(\mathrm{mg} / \mathrm{l})$ & 2551 & 2981 & $92 \%$ & 50 & 952 & 997 & $95 \%$ & 47 \\
$\mathrm{COD}(\mathrm{mg} / \mathrm{l})$ & 6880 & 6710 & $89 \%$ & 34 & 2212 & 2439 & $93 \%$ & 33 \\
$\mathrm{~N}-\mathrm{KN}(\mathrm{mg} / \mathrm{l})$ & 313 & 264 & $82 \%$ & 31 & 117 & 117 & $90 \%$ & 30 \\
$\mathrm{~N}_{-} \mathrm{NH}_{4}^{+}(\mathrm{mg} / \mathrm{l})$ & 69 & 72 & - & 34 & 29 & 34 & - & 33 \\
$\mathrm{~N}_{-} \mathrm{NO}_{3}{ }^{2-}(\mathrm{mg} / \mathrm{l})$ & 215 & 158 & - & 16 & 137 & 104 & - & 19 \\
$\mathrm{P}_{\mathrm{PO}}{ }^{3-}(\mathrm{mg} / \mathrm{l})$ & 12,7 & 9,2 & - & 5 & 4,2 & 1,0 & - & 3 \\
$\mathrm{TP}(\mathrm{mg} / \mathrm{l})$ & 47 & 46 & - & 8 & 27 & 28 & - & 6 \\
\hline
\end{tabular}

The leachates are not septic $(263 \pm 85 \mathrm{mV} / \mathrm{ENH})$ and will not impact negatively the performances of the WWTP. However, a complementary treatment of these leachates must be done and designed according to on the fluxes of COD calculated with the percolation volume (approx. 60\% of the feeding volume for a specific load of $30 \mathrm{kgSS} \cdot \mathrm{m}^{-2} \cdot \mathrm{yr}^{-1}$ ).

Table 5: Leachate quality and removal performances for pilots fed with the mixture activated and septage with a six beds frequency and sand filtration layer

\begin{tabular}{lcccc}
\hline Parameters & $\begin{array}{c}\text { Mean } \\
\text { result }\end{array}$ & $\begin{array}{c}\text { Standard } \\
\text { deviation }\end{array}$ & $\begin{array}{c}\text { Removal } \\
\text { rate }\end{array}$ & $\begin{array}{c}\text { Nbr. of } \\
\text { sample }\end{array}$ \\
\hline pH & 7,9 & 0,4 & - & 6 \\
Cond $\left(\mu \mathrm{S} . \mathrm{cm}^{-1}\right)$ & 1572 & 209 & - & 7 \\
$\mathrm{SS}(\mathrm{mg} / \mathrm{l})$ & 284 & 290 & $96 \%$ & 14 \\
$\mathrm{COD}(\mathrm{mg} / \mathrm{l})$ & 805 & 670 & $92 \%$ & 8 \\
$\mathrm{~N}-\mathrm{KN}(\mathrm{mg} / \mathrm{l})$ & 43 & 38 & $88 \%$ & 8 \\
$\mathrm{~N}^{-N_{4}}{ }^{+}(\mathrm{mg} / \mathrm{l})$ & 12 & 11 & - & 8 \\
$\mathrm{~N}^{2} \mathrm{NO}_{3}{ }^{2-}(\mathrm{mg} / \mathrm{l})$ & 29 & 21 & - & 7 \\
\hline
\end{tabular}

The leachate quality resulting of the mixture is clearly better than the one of septage alone (Table 5), thanks to the dilution effect of activated sludge. Nevertheless, in term of flux, SS removal performances are not significantly different than the one obtained with septage only. This tends to show that the flocculating improvement of septage mixed with activated sludge is not very effective. Nevertheless it is possible that the shear stress imposed to the floc during mixing may change the particle structure and size.

\section{Activated sludge and septage mixture: an interesting strategy in terms of infiltration rate?}

If treating simultaneously both types of sludge mixed, directly by reed bed filters could appear interesting in first approach, we saw that benefits in terms of dewaterability and filtration efficiency are not evident compared to the treatment of septage alone. 


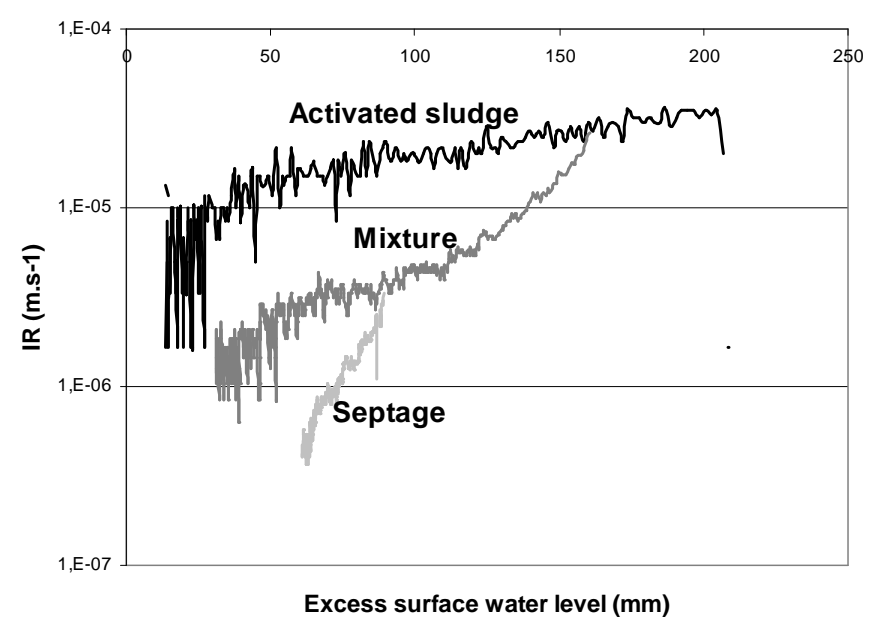

Figure 8: Variations of the infiltration rates (IR) for 3 different sludges at a same solid load in pilots with a sand filtration layer and at the second day of feeding

These different dewatering results obtained on both kinds of sludge with the same loading strategy can be explained by their different hydraulic loading rate (HLR). In fact pilots fed with septage and mixture were loaded at $3 \pm 1 \mathrm{~cm} \cdot \mathrm{m}^{-2} \cdot \operatorname{load}^{-1}$ and $11 \pm 6 \mathrm{~cm} \cdot \mathrm{m}^{-2} \cdot \mathrm{load}^{-1}$ respectively, resulting in a higher humectation of the deposits in the pilot fed with the mixture. Moreover, a clogging phenomena, due to the thin solid particles of septage, appears also with the mixture and affects the infiltration rate compared to the one of activated sludge (Figure 8). This clogging leads to a longer drainage $(8,22$ and $22 \mathrm{~h}$ for activated, mixture and septage sludge respectively) resulting in a higher residual humidity.

Therefore, the feeding and rest periods should be adapted following the drainage and drying dynamics for a suitable treatment. A longer rest period allowed by a 10 beds feeding frequency seems to be also necessary for the mixture treatment.

\section{The CST as an operating tool for sludge drying reed bed?}

Figure 9 shows the tendency that high CST impacts negatively the drainage rate and consecutively the drying efficiency (Figure 10) in winter.

As winter temperatures have a low influence on sludge drying rate, the dewatering concerns mainly the water that could be drained by gravity force (interstitial and free water). Consequently, when evapotranspiration is low the CST that is closed to the free water content, seems to govern partly the dewatering performances (Figure 10).

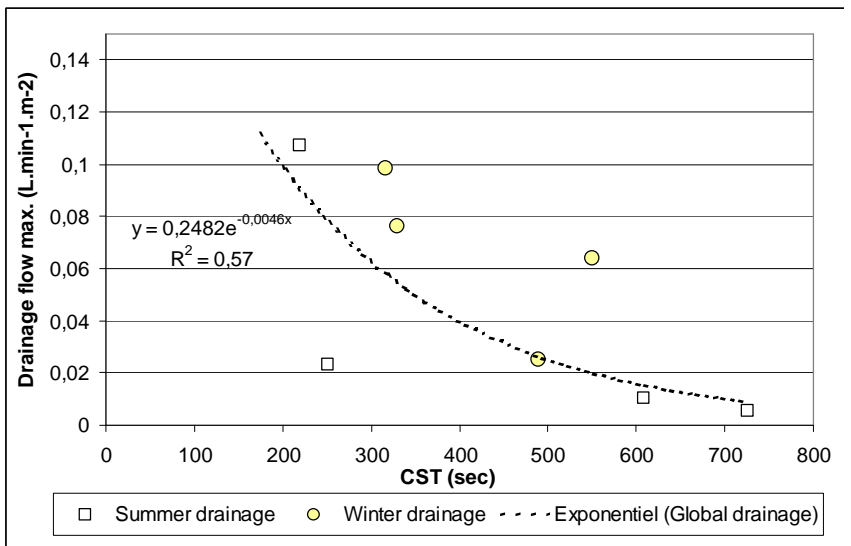

Figure 9: Maximum outflow on pilots fed with septage the first day of the loading cycle following the CST

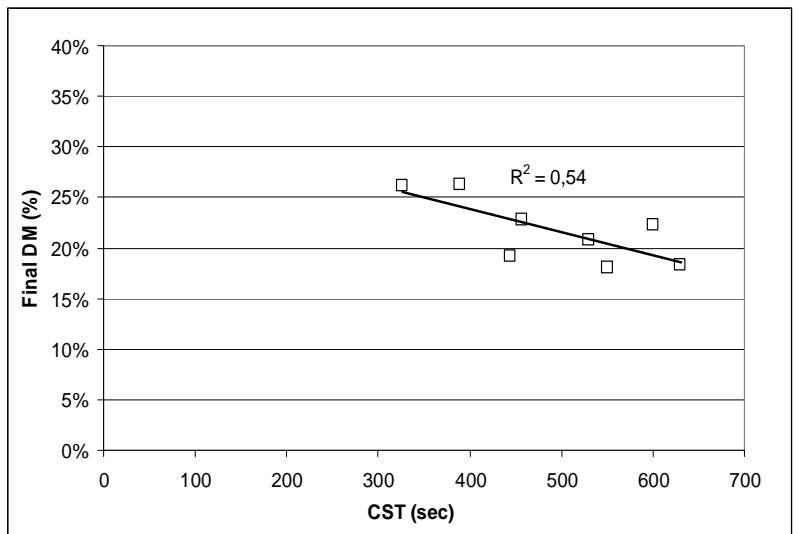

Figure 10: Final DM content of the sludge deposit on both filtration media at the end of the rest period in winter $(9 \pm$ $5^{\circ} \mathrm{C}$ ) vs CST of the septage 
However, if this negative impact of high CST values over $500 \mathrm{sec}$ is not too detrimental with specific loads of $30 \mathrm{~kg} \mathrm{SS} \cdot \mathrm{m}^{-2} \cdot \mathrm{yr}^{-1}$ we do not know yet what the result will be with higher specific loads in terms of density of reeds at the end of winter with the negative influence of both accumulated amounts of organic matter and septicity. Will they be healthy enough to offset the low winter drainage by a strong evapotranspiration in summer?

\section{CONCLUSION}

The following conclusions can be learned from our experiments conducted on pilot-scale reed beds for septage treatment with a specific loading rate which does not exceed $30 \mathrm{~kg} \mathrm{SS} . \mathrm{m}^{-2} . \mathrm{yr}^{-1}$ during the commissioning period:

1. Initial planting density of 9 pots $/ \mathrm{m}^{2}$ enabled a good reed cover after the second growing season $\left(>250\right.$ stems. $\mathrm{m}^{-2}$ ). The sludge quality does not impact the reed growth.

2. The vegetal compost layer is a better growing media but has a lower filtration capacity than sand, the leachates are more concentrated in SS and COD. Whereas the dewatering performances were similar for both media. Thus, a sand layer filtration seems to be preferable for septage treatment at this loading rate.

3. The leachate is still concentrated and needs a suitable complementary treatment before being rejected in receiving bodies. Nevertheless, removal rates higher than $90 \%$ in COD and SS and a bit lower for KN represent so far a beneficial primary treatment, simple and easy to operate.

4. A maximum of 3 days feeding period and 20 days of rest is recommended for a 6 beds configuration without risk of reeds wilting in summer.

5. The drying and mineralization efficiencies on a one year old stored sludge, give to this latter the status of solid and stabilized sludge according to the French regulation.

6. An effective pathogen removal is observed in the bottom layer of the sludge deposit.

7. Improving septage dewaterability with an activated sludge dilution has not been conclusive, especially if we consider the surplus of equipment and work induced to mix them.

8. Capillary suction time can be used to give an order of magnitude in terms of dewatering and drying.

The study will continue with expected specific loads close to $50 \mathrm{~kg} \mathrm{SS} \cdot \mathrm{m}^{-2} \cdot \mathrm{yr}^{-1}$.

\section{ACKNOWLEDGEMENTS}

The authors wish to thank the different partners involved in this study: ADEME, SINT company, Syndicat Intercommunal d'Assainissement du Pays d'Albon, Veolia water, and the French Water Agency. 


\section{REFERENCES}

AFNOR. (1994). NF V 08-056 - Dénombrement des Clostridium perfringens par comptage des colonies à 37 degrés Celsius - Méthode de routine.

AFNOR. (1998). NF EN ISO 7899-1 - Qualité de l'eau - Recherche et dénombrement des entérocoques intestinaux dans les eaux de surface et résiduaires - Partie 1 : méthode miniaturisée (nombre le plus probable) par ensemencement en milieu liquide.

AFNOR. (2002). NF V08-053 - Microbiology of food and animal feeding stuffs - Horizontal method for the enumeration of beta-glucuronidase positive Escherichia coli using 5bromo-4-chloro-3-indolyl beta-D-glucuronide by colony count technique at $44{ }^{\circ} \mathrm{C}$ Routine method.

AFNOR. (2005a). Recueil Normes \& Réglementations Environnement. Qualité de l'eau Vol 1 $(552 p)$ et Vol 2 (502p).

AFNOR. (2005b). XP U 44-162 Amendements organiques et supports de culture Fractionnement biochimique et esimation de la stabilité biologique, pp. 16.

Burgoon, P.S., Kirkbride, K.F., Henderson, M. and Landon, E. (1997). Reed beds for biosolids drying in the arid northwestern United States. Water Science and Technology, 35(5

Oxford, United Kingdom), 287-292.

Chen, G.W., Lin, W.W. and Lee, D.J. (1996). Cappilary suction time (CST) as a measure of sludge dewaterability. Water Science and Technology, 34(3-4), 443-448.

Hofmann, K. (1990). Use of phragmites in sewage sludge treatment. Constructed Wetlands inb Water Pollution Control (Adv. Wat. Pollut. Control) Vol. 11, 269-277.

Huisman, M. and Van Kesteren, W.G.M. (1998). Consolidation theory applied to the capillary suction time (CST) apparatus. Water Science and Technology, 37(6-7), 117-124.

Karr, P.R. and Keinath, T.M. (1978). Influence of particle size on sludge dewaterability. Journal of the Water Pollution Control Federation, 50(8), 1911-1930.

Koottatep, T., Surinkul, N., Polprasert, C., Kamal, A.S.M., Koné, D., Montangero, A., Heinss, U. and Strauss, M. (2005). Treatment of septage in constructed wetlands in tropical climate: Lessons learnt from seven years of operation. Water Science and Technology, 51(9), 119-126.

Kopp, J. and Dichtl, N. (2000). Prediction of full-scale dewatering results by determining the water distribution of sewage sludges, Water Science and Technology, pp. 141-149. Vol. 42.

Liénard, A. (2004). Traitement des matières de vidange en mileu rural. Evaluation technicoéconomique des filières. Cemagref Editions, Antony, Documentation technique FNDAE, 30, 90.

Liénard, A., Duchene, P. and Gorini, D. (1995). A study of activated sludge dewatering in experimental reed-planted or unplanted sludge drying beds. Water Science and Technology, 32(3), 251-261.

Liénard, A. and Payrastre, F. (1996). Treatment of sludge from septic tanks in reed-bed filters pilot plant. 5th International Conference on Wetland Systems for Water Pollution Control, pp. 1-9.

Mellstrom, R.E. and Jager, R.A. (1994). Reed bed dewatering and treatment systems in New England. Journal of New England Water Environment Association, $28(2$

Boston, MA, United States), 164-184.

Nielsen, S. (2003). Sludge drying reed beds. Water Science and Technology, 48(5), 101-109.

Nielsen, S. (2005). Sludge reed bed facilities: operation and problems. Water Science and Technology, 51(9), 99-107.

Nielsen, S. (2007). Helsinge sludge reed bed system: reduction of pathogenic microorganisms. Water Science \& Technology, 56(3), 175-182.

Pabsch, H. (2004). Batch Humification of Sewage Sludge in Grass Beds. Thesis, 153p. 
Pempkowiak, J. and Obarska-Pempkowiak, H. (2002). Long-term changes in sewage sludge stored in a reed bed. The Science of The Total Environment, 297(1-3), 59-65.

Sanin, F.D. and Vesilind, P.A. (1994). Effect of centrifugation on the removal of extracellular polymers and physical properties of activated sludge. Water Science and Technology, $30(8$ pt 8), 117-127.

Vaxelaire, J. and Cezac, P. (2004). Moisture distribution in activated sludges: A review. Water Research, 38(9), 2214-2229. 